\title{
Characterization of Groundwater Discharge to Rivers in the Shire River Basin, Malawi
}

\author{
Laura Kelly ${ }^{1, *}$, Douglas Bertram ${ }^{1}$, Robert Kalin ${ }^{1}$, Cosmo Ngongondo ${ }^{2}$ \\ ${ }^{1}$ Department of Civil and Environmental Engineering, University of Strathclyde, Glasgow, UK \\ ${ }^{2}$ Department of Geography and Earth Sciences, University of Malawi, Chancellor College, Zomba, Malawi
}

\section{Email address:}

laura.kelly.100@strath.ac.uk (L. Kelly),robert.kalin@strath.ac.uk (R. Kalin),douglas.bertram@strath.ac.uk (D. Bertram), cngongondo@cc.ac.mw (C. Ngongondo)

${ }^{*}$ Corresponding author

\section{To cite this article:}

Laura Kelly, Douglas Bertram, Robert M. Kalin, Cosmo Ngongondo. Characterization of Groundwater Discharge to Rivers in the Shire River Basin, Malawi. American Journal of Water Science and Engineering. Vol. 5, No. 4, 2019, pp. 127-138. doi: 10.11648/j.ajwse.20190504.11

Received: October 10, 2019; Accepted: November 4, 2019; Published: November 8, 2019

\begin{abstract}
This study investigates groundwater discharge to rivers in the Shire River Basin, Malawi, using the base flow index (BFI) approach. The BFI represents the baseflow component of a river and is often used as a proxy indicator of groundwater discharge to a river. The smoothed minima method was applied to river flow data from 15 gauges in the Basin (ranging from 1948 to 2012) and the Mann-Kendall (MK) statistical test was used to identify trends in the BFI. The BFI results indicate that groundwater plays an important role in contributing to river flows in the SRB, especially in the dry season. Expressing the BFI as a percentage, these values indicate that annual groundwater discharge to the river's ranges from $19 \%$ in the Rivirivi River to $97 \%$ in the Shire River. Seasonally, minimal difference was found between the annual and the wet season BFI. Generally, the dry season BFI was higher than those of the wet season with most rivers increasing to $>75 \%$. Groundwater data supported the seasonal fluctuations identified in the BFI data, however, there were no groundwater monitoring boreholes in close proximity to any of the river gauges for in-depth analysis. The results also showed long term trends in the BFI data indicating behavioural changes in the river baseflow and groundwater discharge. In some areas, the declines in BFI indicate that groundwater discharge has been reducing over time due to declines in groundwater levels. This is a concern for the sustainable management of water resources in the Basin. The findings of this study provide important new knowledge on the seasonal and long-term behaviour of groundwater discharge to rivers in the Basin which will be crucial for supporting sustainable water resources management practices. The results will be particularly useful to the new National Water Resources Authority within the Malawian Government, who will oversee catchment management plans.
\end{abstract}

Keywords: Baseflow, BFI, Groundwater Discharge, Malawi

\section{Introduction}

Groundwater depletion caused by unsustainable abstractions from our aquifers is a global problem $[1,2]$. This depletion puts the future water security of life on earth at risk. Although pertinent to all countries, it is especially crucial to Africa which is heavily reliant upon groundwater with an estimated $75 \%$ of the population dependent on it as a water resource. Groundwater also has an important environmental use as baseflow to rivers. In connected groundwater-river systems, groundwater discharges from the aquifer year-round to contribute to river flow, with contributions varying dependent on geology, topography, climatic season and anthropogenic activities. In many semi-arid regions, groundwater can maintain river flows during the dry season contributing up to $90 \%$ of the total river flow in some rivers [3]. Thus, when groundwater levels drop, so too does the groundwater discharge to the river, and if this drop is sustained ultimately the groundwater will become disconnected from the river and the river will cease to flow in sustained periods of no rainfall [4-6]. This knock-on effect is also a global problem, with a recent study estimating that for $42-79 \%$ of the catchments where there is currently groundwater pumping, the environmental flow 
limits of the rivers, that is the level required for a healthy river, will be reached by 2050 [7]. Depletion of one of the world's largest rivers, the Ganges, has also recently been attributed to reductions in groundwater baseflow [8]. As such, the groundwater-river connection is critical for sustainable water resources management and can be considered to underpin the Sustainable Development Goal (SDG 6) 'to ensure availability and sustainable management of water and sanitation for all' $[9,10]$.

Quantifying groundwater discharge to rivers is a difficult and challenging task given the complex nature of the interaction. There is a vast body of literature available with countless studies on the topic. Examples from country's across the world include; China [11, 12]; Africa [13-15], South Korea [16], Australia [17], New Zealand [18], Canada [19] and the USA [20, 21]. In many developing world countries, the task of quantifying groundwater discharge is challenged by a lack of data, financial resources and technical staff allocated to execute such studies [3, 22]. Studies therefore often focus on quantifying river baseflow, or the baseflow index (BFI), which is often used as a proxy for groundwater discharge to rivers $[3,20,23,24]$ due to the minimal data requirements. However, comprehensive baseline data on baseflow is still typically lacking in many countries. This baseline data is the prerequisite for sustainable water management approaches such as Integrated Water Resources Management (IWRM) and Conjunctive water use, and further the quantification of the impacts of human pressures and climate change on our water resources.

One example is Malawi in Southern Africa, where groundwater discharge to rivers plays a vital role in maintaining river flows [3]. One of Malawi's most important hydrological systems is the 'Shire River Basin (SRB)' (Figure 1), which is located in the Southern Region and is the only outlet from the prominent Lake Malawi. The SRB is a sub-basin of the Zambezi River which cements its importance on an international scale. The SRB sustains the socio-economic livelihoods of over 5 million people through hydro-electric power generation, irrigated agriculture, aquaculture, transportation, tourism and, urban water supply and water use for the riparian communities [25]. The Shire River is regulated at Liwonde, about $72 \mathrm{~km}$ downstream from Lake Malawi, by the Kamuzu Barrage for hydropower purposes [26]. In recent years, high population density which is predicted to rise to over 8 million in the next 20 years [27] and poverty has led to significant human pressure on its groundwater and river resources. To meet this increased demand for access to clean water, there has been a significant number of new boreholes drilled by the government, non-governmental organizations and the private sector [28]. Further, increased climate variability has affected the SRB, with a lot of uncertainty in the timing and magnitudes of rainfall and river flows. There have been recent reports of declines in groundwater levels and rivers turning to dust, a topic which is being openly discussed [29, 30]. Unfortunately, groundwater monitoring has not been sufficiently monitored in the Basin to support such claims. It's presumed that low season river flows are sustained by baseflow from the underlying aquifers year-round. Specific studies are scarce, only one appears to focus exclusively on baseflow [3], whilst a handful of others consider it to a limited extent [31,32]. As such, quantitative data to describe the groundwater-river connection is lacking. This lack of baseline data is a key limitation to the sustainable management of water resources in the Basin.

Therefore, this study aims to characterize groundwater discharge to rivers in the SRB. Specifically, the objectives were to (1) quantify the annual and seasonal BFI and (2) to evaluate long term trends in the BFI. We use the base flow index method, as detailed in section 2.3, as a proxy indicator of groundwater discharge to a river. The findings of this study are expected to provide important new insights on the behaviour of baseflow in the Basin and generate key baseline data which is required to integrate groundwater and surface water together in the management and development of water resources in the Basin.

This study is part of on-going research in the sustainable development of groundwater in Malawi to support the Government of Malawi in achieving SDG 6.

\section{Material and Methods}

\subsection{Study Area}

The SRB (Figure 1) has a total catchment area of 22,430 $\mathrm{km}^{2}$ and comprises the Shire river catchment (the area that is south of Lake Malawi, and from here defined as) and the Ruo river catchment. The Basin is part of the larger Lake Malawi which drains an area from Tanzania, Malawi and Mozambique. The Basin is not a true hydrological basin but intended as a planning unit as used in the World Bank Funded SRB Management Program (SRBMP) currently being executed by the Government of Malawi [24]. The SRBMP has been tasked with the sustainable planning, managing and development of the natural resources of the SRB through the implementation of Integrated Water Resources Management.

Within the National Water Resources Master Plan (NWRMP) of Malawi, the Shire river catchment is referred to as Water Resource Area (WRA) 1 and the Ruo river catchment is referred to as WRA 14 [29].

The Shire River originates as the only outflow from Lake Malawi and flows south through Southern Malawi $(520 \mathrm{~km})$ to its confluence with the Zambezi River in Mozambique (Figure 1) [27]. It is joined by five major tributaries (Rivirivi, Lisungwe, Wakulumadzi, Mwanza and the Ruo) and has numerous minor tributaries (including Nkasi, Lirangwe and Likhubula). The Ruo River is the largest tributary of the Shire River, originating in Mount Mulanje and flows south-west along the border with Mozambique until it joins the Shire river at Chiromo. Several tributaries join the Ruo including the Lichenya, Likabula, Mloza, Mombezi and Thuchila. The Ruo has a catchment area of 4,760 $\mathrm{km}^{2}, 1,266$ $\mathrm{km}^{2}$ of which lies in Mozambique [33]. The Ruo is thus a 
transboundary river of importance to both Malawi and Mozambique.

The topography of WRA 1 ranges from 0 masl to 1,700 masl (Figure 1). The south of the WRA 1 has some of the lowest-lying lands in Malawi with the floodplains adjacent the Shire River predominately less than 50 masl, making it susceptible to flooding. For example, the southern reach of the Shire burst its banks following torrential rains in 2015 and 2019, leaving 100s of people dead and 1000s homeless. The topography of WRA 14 (i.e. to the west of the Basin) is mainly low lying (typically 500-1000 masl) and drops consistently towards the south. Tributaries typically have steep upper reaches and low gradients further downstream. WRA 14 comprises most of the Mulanje mountains with a peak of approximately 3,000m [33].

Land use in WRA 1 is shown in Figure 2 (a) and mainly comprises cropland; arable agriculture of mainly maize crops, tobacco and sugarcane. There are many designated areas; Mwabvi Game Reserve and Namizimu Forest reserve in the south; Lengwe National Park and Majete Game Reserve in the south-west; Liwonde National Park, Zomba-Malosa Forest, Liwonde Forest Reserve and Liwonde National Park in the north. Outside the designated areas, the land is largely under arable agriculture. Wetlands in the south of the catchment include the Elephant marshes. Most of the land in WRA 14 is dominated by large areas for maize crops, and tea and coffee estates and smaller areas for tobacco. There is a small area of wetland in the north. On the Mulanje Mountains, there is forest land and grassland.

The climate of the SRB reflects that of wider Malawi, being sub-tropical and generally considered bimodal referring to the wet and dry season (1 November-31April, 1 May-31 October respectively) [29]. The average annual rainfall as shown in Figure 2 (b) is $897 \mathrm{~mm} /$ year for WRA 1, and 1,331 mm/year for WRA 14 [34]. The highest rainfall in the Ruo catchment derives from the mountainous topography around Mount Mulanje 850- $>1,200 \mathrm{~mm} /$ year [35]. The average annual temperature ranges from 19 to $26^{\circ} \mathrm{C}$ in WRA 1 and 18 to $26^{\circ} \mathrm{C}$ in WRA 14 [34]. Temperatures can drop to between 4 and $10^{\circ} \mathrm{C}$ for the months of May to August (the Malawi winter) and frost may even occur in isolated areas in June and July [36]. No average annual rainfall or temperature values were available for the wet and dry season.

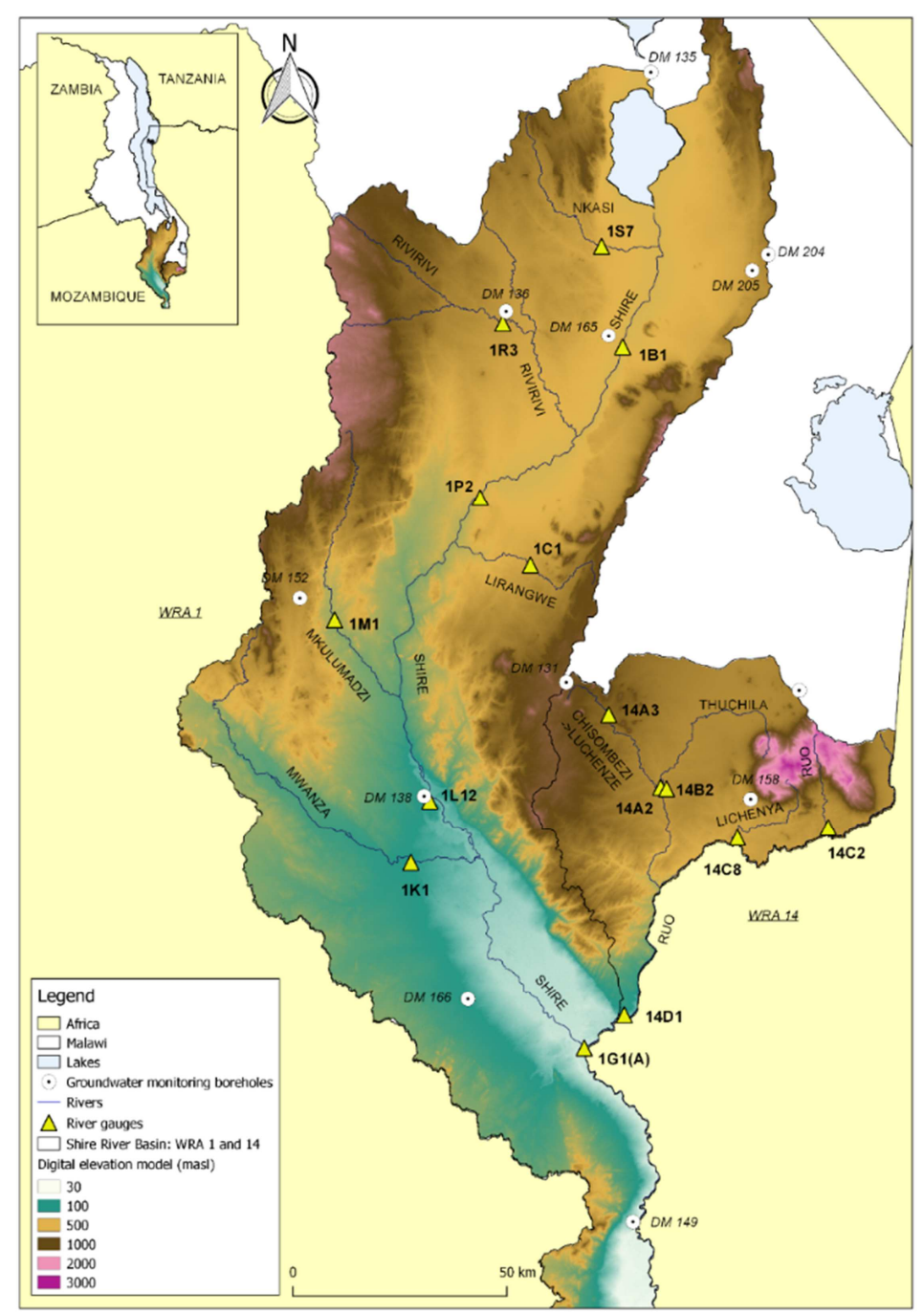

Figure 1. Location of the SRB (WRA 1; Shire catchment and WRA 14; Ruo catchment) in Malawi (insert) and digital elevation model of the SRB with rivers and river gauges in this study. 
Aquifer types which have been identified in Malawi are alluvial aquifers, sedimentary aquifers and basement aquifers (fractured and weathered) [29]. Figure 2 (c) shows the aquifer types in the SRB in a simplified format. The alluvium aquifer underlays the path of the Shire River, with additional coverage in the north and east. The fractured basement is present along the west of the basin, and to the east where it underlays most of the Ruo catchment [37]. More detailed hydrogeological maps of the area are available in the Malawi Hydrogeological and Water Quality Atlas 2018 [35]. Soil texture varies across the basin and includes clay, loam, sandy and several variations [37]. Recent studies outline that some of the aquifer units in the Shire River Basin are transboundary in nature as they are shared with Mozambique [38].

Parameters in the basin are routinely monitored by Government bodies, however, with frequent flooding and budgetary constraints, the ability to collect comprehensive long-term continuous records has not been possible.

Groundwater monitoring is carried out through a network of monitoring boreholes which were established by the Government of Malawi and managed by the Groundwater Division of the Department of Water Resource. Surface water is monitored by a network of river and lake gauges and managed by the Surface Water Division, and climate monitoring is carried out and managed by the Department of Meteorological Services. At present, there are 12 monitoring wells located in the Basin.

Further, a significant effort is currently being made by the Scottish Government Climate Justice Fund (CJF) Water Futures Programme, working in partnership with the Malawian Government, to locate all water points (and associated data) in the country using the Management Information System (MIS); mWater [40]. Data is actively being used in several various research areas including the management of rural groundwater supply [41], the impact of Stranded Assets for rural water supply [42] and the design of groundwater-quality monitoring networks [43]. The most common occurring water points in the SRB appear to be boreholes, piped taps and dug wells, but can also include springs, rainwater, bottled water amongst others. To date (October 2019), 18,386 boreholes and 10,296 public taps have been mapped in the Basin.

\subsection{Data}

This study focused on data from a total of 15 river gauges within the SRB; comprising 9 gauges from WRA 1 and 6 gauges from WRA 14. Other gauges do exist; however, no data were obtained for them. Within WRA 1, the Shire river is monitored by four gauges; 1B1, 1G1 (A), 1L12 and 1P2. Several tributaries of the Shire are also monitored; the Rivirivi by $1 \mathrm{R} 3$, the Nkasi by $1 \mathrm{~S} 7$, the Mkurumadzi by $1 \mathrm{M} 1$, the Mwanza by $1 \mathrm{~K} 1$ and the Lirangwe by $1 \mathrm{C} 1$. Within WRA 14, two gauges monitor the main Ruo river; 14C2 and 14D1. Two major tributaries of the Ruo are also monitored; the Lichenya by $14 \mathrm{C} 8$ and the Thuchila by $14 \mathrm{~B} 2$. Further, the
Luchenze (a tributary of the Thuchila) is monitored by 14A2, and the Chisombezi (a tributary of the Luchenze) is monitored by $14 \mathrm{~A} 3$.

The Kamuzu Barrage is located on the upstream reach of the Shire and regulates the flow from the lake into the river [44]. The levels of Lake Malawi therefore highly influence the flows in the Shire River. For this reason, gauges on the Shire have been excluded from previous hydrological studies, for example during the development of a pilot water resources management software incorporating hydrological models in the area [45]. However, for completeness and to explore all gauge data available, this study has chosen to include the gauges on the river Shire.

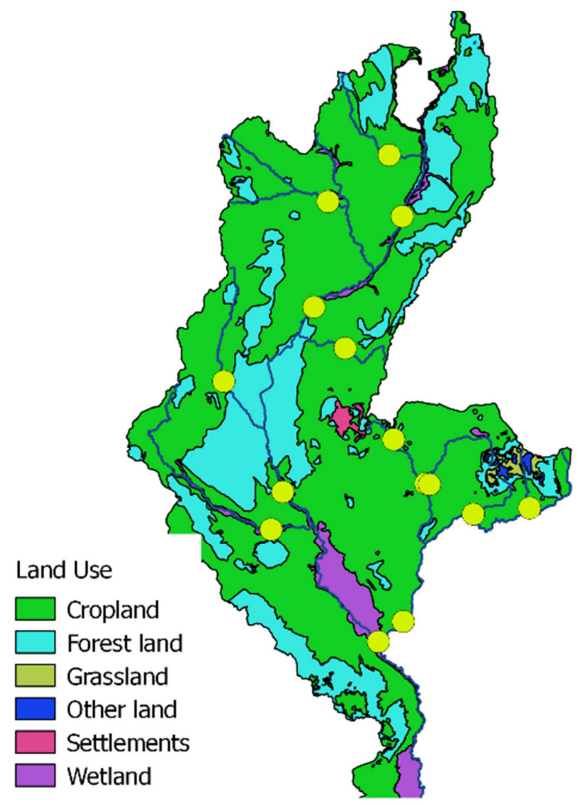

(a)

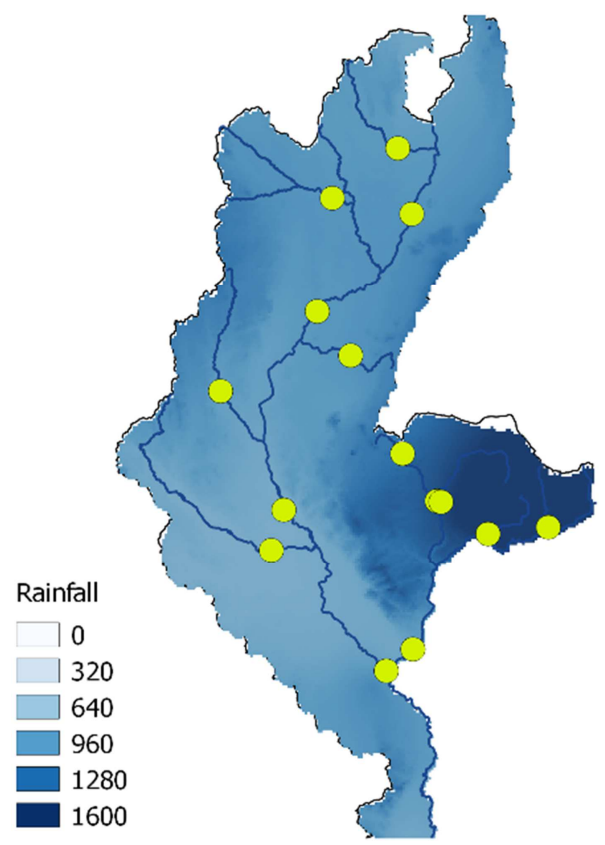

(b) 


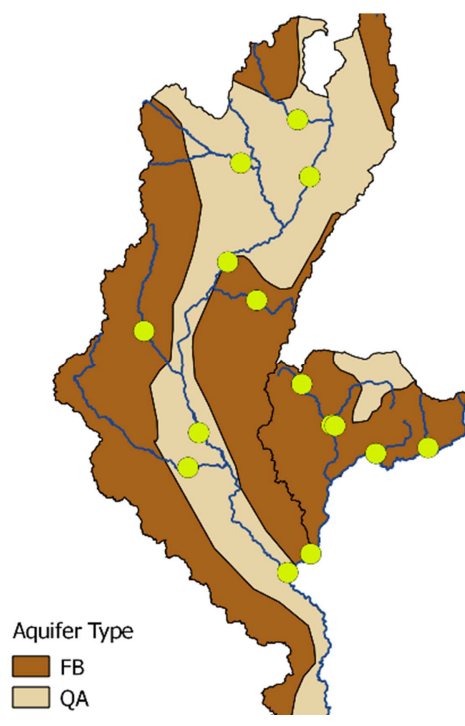

(c)

Figure 2. (a) Land use map [32], (b) Rainfall (mean annual), and (c) Aquifer types [GIS files are freely available from the SRB Planning Portal [37]].

Daily flow rate data were available for each of the gauges as follows; 1B1 Shire (1948-2012), 1C1 Lirangwe (1951-2005), 1G1(A) Shire (1953-2009), 1K1 Mwanza (1951-1997), 1L12 Shire (1976-2010), 1M1 Mkurumadzi (1980-2008), 1P2 Shire (1952-2005), 1R3 Rivirivi (1952-2004), 1S7 Nkasi (1961-1997), 14A2 Luchenze (1954-2002), 14A3 Chisombezi (1962-2000), 14B2 Thuchila (1951-2003), 14C2 Ruo (1953-2008), 14C8 Lichenya (1959-2002) and 14D1 Ruo (1980-1991). Data coverage appears varied ranging from 11-65 years, however, it is expected to be sporadic and have missing values throughout. The data were obtained from the Surface Water Division of the Department of Water Resources of Malawi.

This study also examined groundwater levels in the Basin which are monitored via 11 monitoring boreholes at; Balaka Water Office (DM 136), Mtaja Water Office (GN 204), Ngabu Water Office (GN 166), Kaombe Dam (GN 205), Mwanza Prison (DM 152), Chikwawa Water Office (DM 138), M'manga School (GN 165), Mangochi Water Office (DM 135), Nansomba School (GN 158), Mulanje Water Office (DM 148) and Nsanje Water Office (DM 149). Data were available for each borehole from 2009-2015, however, the data is sporadic in nature. One of the original 12 boreholes constructed was vandalized shortly after completion in 2009/2010 and as such no data was available. Further, Nansomba School (GN 158) and Chikwawa Water Office (DM 138) did not have enough data for analysis. The Groundwater Division of the Department of Water Resources of Malawi provided the data.

\subsection{Baseflow Separation Approach and Statistical Rend Analysis}

Baseflow separation was selected to analyze the river data and determine BFI. As the river data was sporadic in nature, this study followed the approach set out in a recent study which demonstrated how to work with sporadic river data to quantify temporal variations in BFI [3]. The approach uses the BFI programme which implements the Institute of Hydrology's filtering method called the 'smoothed minima' procedure [46]. Further information including the baseflow separation steps followed can be found in Kelly et al [3]. The approach used in this study assumes that baseflow is derived entirely from groundwater discharge from the aquifer, however, it is appreciated that some flow may be also derived from interflow and other stored sources.

Three assessment periods selected for the baseflow separation were based on those used by the Malawi Water Resources Department; annual (1st November-31st October), the wet season (1st November-30th April), and the dry season (1st May-31st October).

The direction and significance of trends in the BFI series were determined by the non-parametric Mann-Kendal (MK) trend test $[47,48]$. The test is recommended for the analysis of trends in hydrometeorological variables by the World Meteorological Organisation (WMO) and is popular in the literature [49-51]. The test was applied using the statistical programme XLSTAT [52]. The following test parameters were adopted for the test: 'normal' MK test, 'exact p' method, ignore missing data' significance level of $1 \%$. Further information on the selection of the test parameters can be found in Kelly et al [3].

\section{Results and Discussion}

\subsection{Seasonal Behavior of Groundwater Discharge to Rivers}

Average annual and seasonal BFI (wet and dry) for the gauges were determined and the results are presented in Table 1.

This study found average annual BFIs for the gauges as follows; 0.97, 0.95, 0.92 and 0.90 for Shire (1B1, 1G1(A), 1L12 and 1P2), 0.48 for Lirangwe (1C1), 0.38 for Mwanza (1K1), 0.64 or Mkurumadzi (1M1), 0.19 for Rivirivi (1R3), 0.32 for Nkasi (1S7), 0.43 for Chisombezi (14A2), 0.36 for Thuchila (14B2), 0.46 and 0.43 for Ruo (14C2 and 14D1), and 0.40 for Lichenya (14C8) (Table 1). Expressing the BFI as a percentage, these values indicate that annual groundwater discharge to the rivers ranges from approximately $19 \%$ (Rivirivi) to $97 \%$ (Shire). BFI is expected to vary across studies based on the difference in method and assessment periods used, however, its useful to consider the existing literature. For example, some of this study's findings are consistent with the average annual BFI sourced from the Malawian HYDATA system in use by the Malawi Surface Water Division, matching exactly or to the first decimal place. HYDATA reports an average annual BFI of 0.97 (1B1), 0.96 (1G1), 0.95 (1L12), 0.41 (14A2), 0.40 (14B2), 0.36 (14C2) and 0.51 (14D1). There was no BFI available from HYDATA for the other gauges. The results differ to global studies by UNESCO [45] and Beck et al. [53] who reported annual BFIs for Malawi in the range of 0.6 to 0.7 and 0.6 to 0.8 
respectively. They also differ to a study by Reference 32 who reported a BFI of 0.35 for $1 \mathrm{R} 3$ (Rivirivi) which is much higher than this studs BFI of 0.19. Based on this study's annual average BFI values, these rivers are considered perennial in

nature, that is, flowing year-round and as there is minimal rainfall in Malawi in the dry season, the dry season flow is expected to be sustained by groundwater discharge.

In addition to determining annual baseflow, it is now widely accepted and appreciated that baseflow should be determined on a seasonal basis $[3,20]$. This study presents the first findings on seasonal BFI in the SRB. For all gauges assessed, the results found minimal difference between the annual and the wet season BFI. In the dry season, except for $14 \mathrm{C} 2$ and $14 \mathrm{C} 8$ and the gauges on the Shire which are discussed below, all BFIs increased to over 0.75 , or $75 \%$ of the dry season flow was attributed to groundwater discharge from the aquifer. For example, 14D1 had a BFI of 0.43 in the wet season increasing to 0.70 in the dry season. This increase in BFI in the dry season is indicative of permeable catchment geology, whereby the catchment stores water during the wet season with some discharge to the river, and during the dry season, continues to discharge to the river to sustain flows when rainfall and surface runoff is reduced to a minimum [3]. Under these conditions, we would expect to see increasing groundwater levels during the wet season as rainfall infiltrates the ground and recharges the groundwater table, and decreasing groundwater levels during the dry season, as rainfall declines to a minimum, and groundwater is used up. As such, evaluation of groundwater levels near the river gauges would help to provide support for the seasonal variations in BFI.

Table 1. Results of average annual and seasonal BFI analysis for the gauges in the SRB; Grouped into Shire River, Ruo River and tributaries.

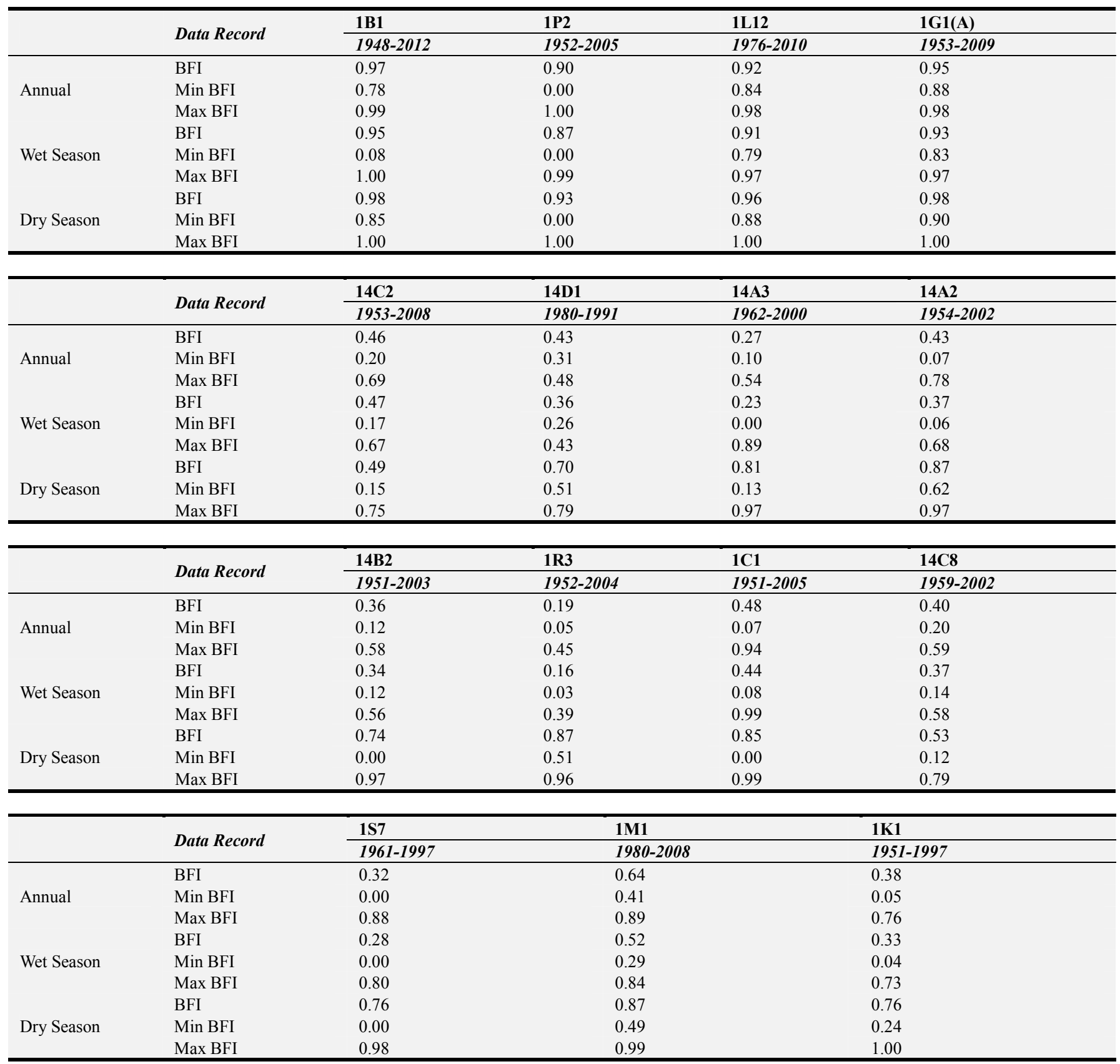


Unfortunately, there were no groundwater monitoring boreholes near any of the gauges, all boreholes being located at least $+2 \mathrm{~km}$ away from any gauge. Groundwater level data at several monitoring boreholes did indicate seasonal fluctuations in line with the wet and dry season. The expected pattern is seen clearly over several hydrological years at Balaka Water Office (DM 136), Mtaja Water Office (GN 204), Ngabu Water Office (GN 166), Kaombe Dam (GN 205) and Mwanza Prison (DM 152), M'manga Water Office (GN 165) and Mulanje Water Office (DM 148) (Figure 3). Generally, at these boreholes, we see the groundwater levels increase during the wet season (November-April), and decrease during the dry season (May-October). In contrast, Nsanje Water Office (DM 149) showed no apparent seasonal fluctuations (Figure 4).

Gauges $14 \mathrm{C} 2$ and $14 \mathrm{C} 8$ do not see significant increases in the dry season BFI. The wet season BFI for 14C8; 0.37, increased to only 0.53 in the dry season. Similarly, the wet season BFI for $14 \mathrm{C} 2 ; 0.47$, increased marginally to 0.49 .
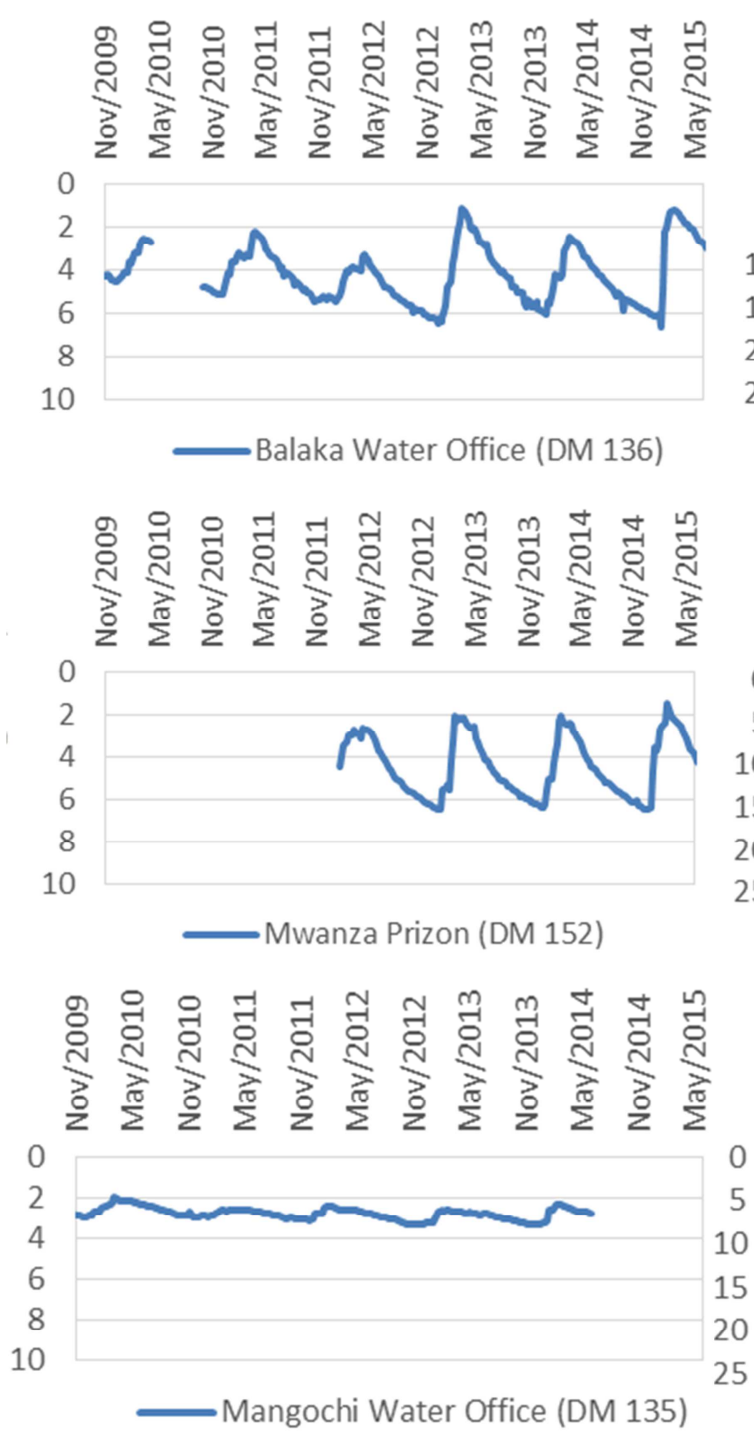$$
20
$$$$
25
$$

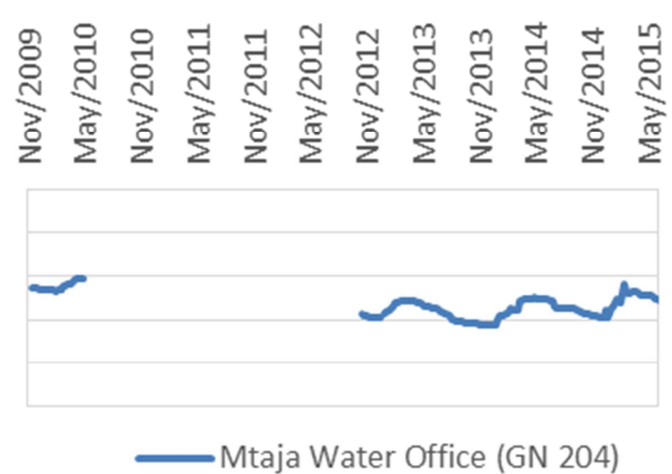

5$$
\text { (1) }
$$

These results indicate that although water is being stored in the wet season, it's to a much lesser extent. The lower dry season BFI here, when compared to those over 0.75 , can be attributed to spatial variations in the geology and rainfall which contribute to the control of baseflow. 14C8 drains a small part of the west side of Mount Mulanje and this area receives the highest rainfall in the Basin $(>1,200 \mathrm{~mm} /$ year) [35] and 14C2 drains a large part of the eastern part of Mount Mulanje and also receives high rainfall.

Interestingly, all the gauges on the Shire river (1B1, $1 \mathrm{G} 1(\mathrm{~A}), 1 \mathrm{~L} 12$ and $1 \mathrm{P} 2$ ) show minimal variations in BFI between the annual, wet and dry season. This is attributed to the influence of Kamuzu Barrage which regulates the flow in the Shire river, and to a certain degree, the water levels of Lake Malawi [44].

Overall, the BFI results display considerable variability within the annual and wet season BFI in all gauges, as shown by the minimum and maximum BFIs Table 1.
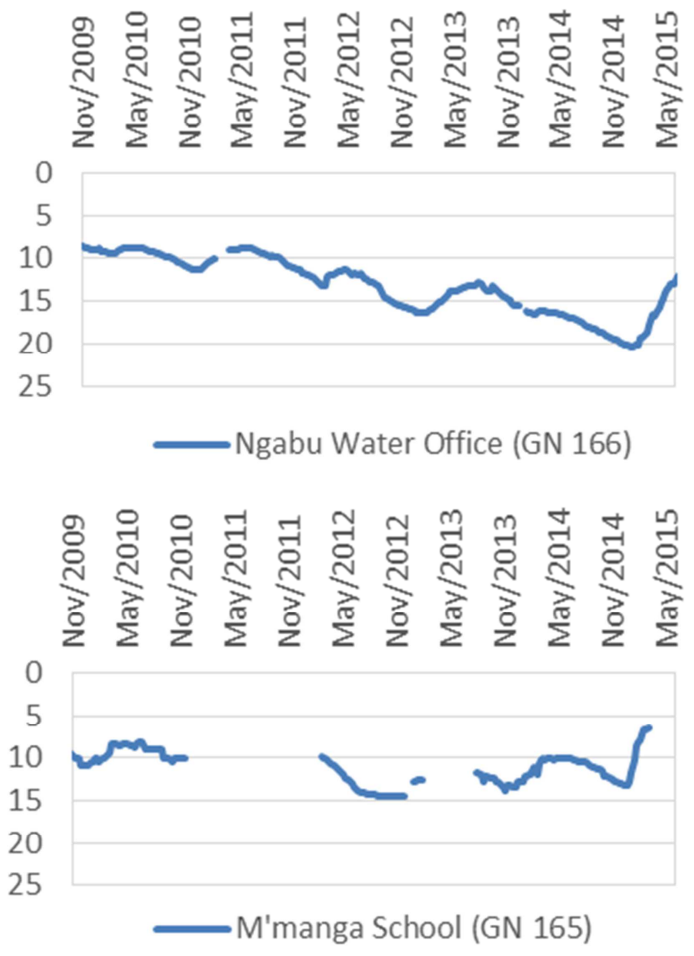

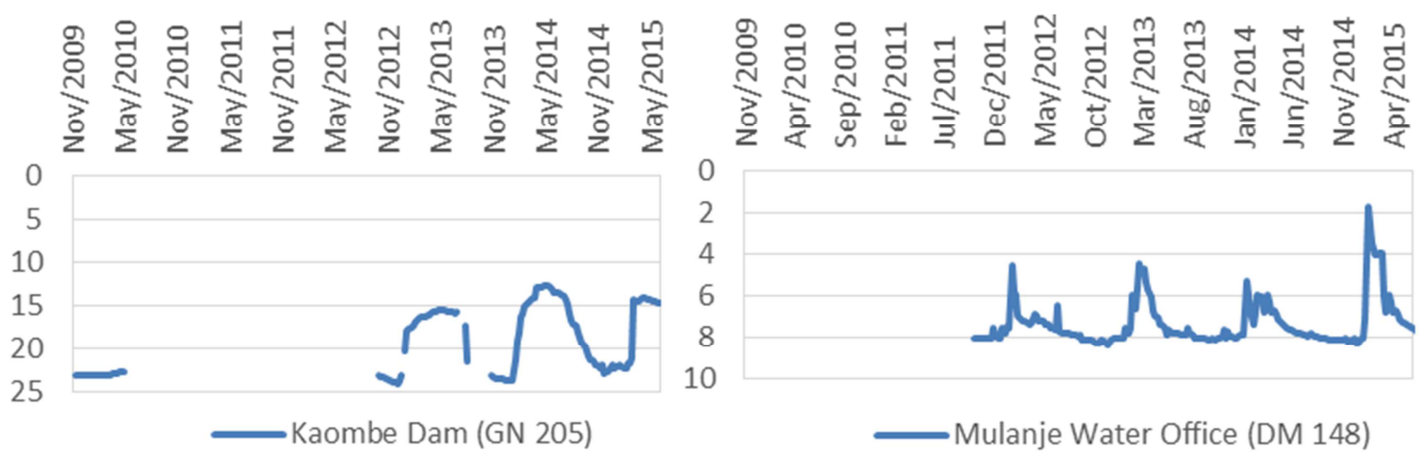

Figure 3. Groundwater monitoring boreholes in the SRB showing seasonal fluctuations in groundwater level between the wet season (1st November-30th April) and the dry season (1st May-31st October). Y axis shows Groundwater Level ( $m$ below ground)

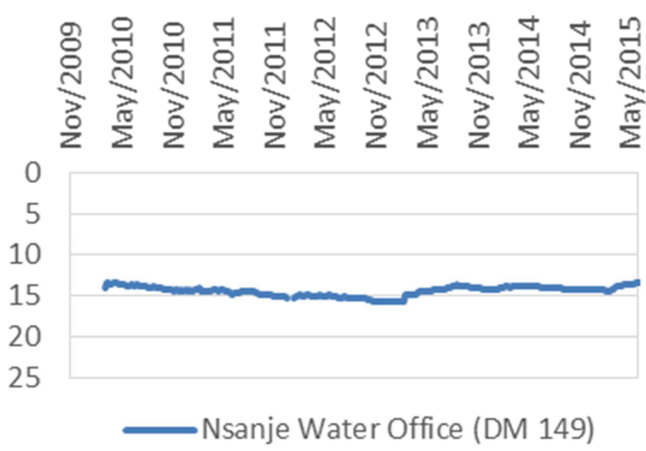

Figure 4. Groundwater monitoring borehole in the SRB with seasonal fluctuation between wet and dry season not apparent. $Y$ axis shows Groundwater Level ( $m$ below ground)

\subsection{Long Term Trends in Groundwater Discharge to Rivers}

This study presents the first comprehensive findings on detecting long term trends in BFI in the SRB. The MK test was used to identify statistically significant trends in the BFI and the results are presented in Table 2.

No trend in BFI was detected in the annual, wet or dry season data for gauge 1B1 (Shire), 1G1(A) (Shire), 1K1 (Mwanza), 1P2 (Shire), 1R3 (Rivirivi), 14A2 (Luchenze) and 14D1 (Ruo). The absence of a trend suggests that groundwater discharge to these rivers has remained stable over the assessment periods. A stable baseflow and feeding aquifer over a prolonged period suggest these catchments are well-managed catchment with minimal impacts from anthropogenic activities.

An increasing trend in BFI in the annual and wet season data was found at 1C1 (Lirangwe), 1S7 (Nkasi) and 14C8 (Lichenya), however, no trend was found in the dry season data. Further, an increasing trend in BFI in the annual and wet season data was found at $14 \mathrm{C} 2$ (Ruo), but interesting, a trend was also evident in the dry season data. These increases in BFI show that over the assessment period, the river has become more dependent on baseflow in the annual and wet season periods, which indicates that groundwater discharge to the river has increased. Such increases may be attributed to increases in groundwater levels arising from prolonged increases in rainfall [54], increases in forest cover or artificial recharge. Statistically stationery trends in rainfall for the Southern Region of Malawi have been reported, however, it's noted that specific stations showed statistically significant increasing trends [55]. An increase in baseflow associated with an increase in forest cover has also been reported in the Shire River catchment (1989-2002) when running land conversation scenarios, through use of a hydrological model and land cover mapping from satellite images [56]. It is unknown if there is any artificial recharge in the Basin.

In contrast, decreasing trends were seen in other gauges. For example, a decreasing trend in BFI for the annual and wet season data was found for 1L12 (Shire) and 14A3 (Chisombezi), and 1L12 also had a decreasing trend in the dry season data. 1M1 (Mukurumadzi) and 14B2 (Thuchila) had a decreasing trend in BFI for the wet season, however, no trend was found in the annual and dry season data. Decreasing trends in BFI shows a decrease in the proportion of the river which is baseflow. This can indicate an imbalance in the catchment system and indicates that groundwater discharge, and thus groundwater levels have been decreasing in these areas. Previous research has demonstrated that baseflow calculated from river data may be used as a proxy for changes in groundwater level elevation over time [57]. Unfortunately, the quality and duration of the groundwater monitoring data as shown in Figure 3 and Figure 4 has been sporadic and sparse and as such it has not been possible to confirm these trends. Such decreases, especially in the dry season, are especially critical in the SRB where groundwater discharge to rivers is required to sustain dry season flows, albeit reduced flows.

Decreases in baseflow may be attributed to deforestation in the catchment [49]. For example, a decrease in mean annual baseflow associated with deforestation in the upper Shire River catchment from 1989-2002 has been previously reported [58]. There is also evidence of extensive deforestation in the SRB with the annual deforestation rate estimated at $2.7 \%$ [36]. Further studies, although not specifically targeting baseflow, investigated how deforestation has impacted on hydrological regimes in the SRB. For example, Chimtengo [32] showed increases in high flows, decrease in low flows, and an increase in zero flow days in the Rivirivi catchment (1992-2008) and attributed much of these changes to deforestation in the area. 
Contrastingly, the study also showed that the Mpira River (a headwater stream of the Rivirivi River) had a more stable BFI regime due to more sustainable catchment practices. Over abstraction of groundwater can also cause declines in the groundwater table and thus groundwater discharge to the river [38]. This scenario is presumed in Malawi due to the tens of thousands of water points which now exist across the country [38, 40, 43] although little evidence could be found in the literature to support this claim.

Table 2. Mann Kendall statistical results for BFI for gauges in the SRB; Grouped into Shire River, Ruo River and all Tributaries.

\begin{tabular}{|c|c|c|c|c|c|}
\hline & \multirow{2}{*}{ Data Record } & 1B1 & $1 P 2$ & $1 \mathrm{L12}$ & 1G1(A) \\
\hline & & $1948-2012$ & 1952-2005 & $1976-2010$ & 1953-2009 \\
\hline \multirow{2}{*}{ Annual } & MK 'S' & -276 & -66 & -26 & 196 \\
\hline & Trend & No Trend & No Trend & Decreasing & No Trend \\
\hline \multirow{2}{*}{ Wet Season } & MK 'S' & -209 & \multirow{2}{*}{$\begin{array}{l}-85 \\
\text { No Trend }\end{array}$} & -63 & 196 \\
\hline & Trend & No Trend & & Decreasing & No Trend \\
\hline \multirow{2}{*}{ Dry Season } & MK 'S' & -318 & \multirow{2}{*}{$\begin{array}{l}-102 \\
\text { No Trend }\end{array}$} & -40 & 190 \\
\hline & Trend & No Trend & & Decreasing & No Trend \\
\hline & \multirow{2}{*}{ Data Record } & $14 \mathrm{C} 2$ & 14D1 & $14 \mathrm{~A} 3$ & $14 \mathrm{A2}$ \\
\hline & & $1953-2008$ & 1980-1991 & $1962-2000$ & 1954-2002 \\
\hline \multirow{2}{*}{ Annual } & MK 'S' & 414 & -6 & -120 & 10 \\
\hline & Trend & Increasing & No Trend & Decreasing & No trend \\
\hline \multirow{2}{*}{ Wet Season } & MK 'S' & 338 & \multirow{2}{*}{$\begin{array}{l}-6 \\
\text { No Trend }\end{array}$} & -153 & 1 \\
\hline & Trend & Increasing & & Decreasing & No Trend \\
\hline \multirow{2}{*}{ Dry Season } & MK 'S' & 515 & -3 & 54 & 150 \\
\hline & Trend & Increasing & No Trend & No Trend & No Trend \\
\hline & \multirow{2}{*}{ Data Record } & 14B2 & $1 \mathrm{R3}$ & $1 \mathrm{C1}$ & $14 \mathrm{C} 8$ \\
\hline & & $1951-2003$ & 1952-2004 & $1951-2005$ & 1959-2002 \\
\hline \multirow{2}{*}{ Annual } & MK 'S' & -89 & -39 & 138 & 191 \\
\hline & Trend & No Trend & No Trend & Increasing & Increasing \\
\hline \multirow{2}{*}{ Wet Season } & MK 'S' & -141 & \multirow{2}{*}{$\begin{array}{l}-63 \\
\text { No Trend }\end{array}$} & 171 & 283 \\
\hline & Trend & Decreasing & & Increasing & Increasing \\
\hline \multirow{2}{*}{ Dry Season } & MK 'S' & -83 & -47 & 135 & 195 \\
\hline & Trend & No Trend & No Trend & No Trend & No Trend \\
\hline & & $1 \mathrm{~S} 7$ & & & $1 \mathrm{~K} 1$ \\
\hline & Data Record & 1961-1997 & & & 1951-1997 \\
\hline Annual & MK 'S' & 168 & -2 & & -79 \\
\hline Annual & Trend & Increasing & & & No Trend \\
\hline & MK 'S' & 174 & -3 & & -131 \\
\hline Wet Season & Trend & Increasing & & & No Trend \\
\hline & MK 'S' & 133 & -2 & & -159 \\
\hline Dry Season & Trend & No Trend & $\mathrm{N}$ & & No Trend \\
\hline
\end{tabular}

The above BFI results show how wet season and dry season BFI can vary significantly from annual values. They also provide evidence of long-term behavioural changes in groundwater discharge to rivers in the SRB over the assessment period. These findings in the seasonal and long-term behaviour of groundwater discharge to rivers have important implications for practice and in future scheme appraisals linked to water resources in the Basin. For example, BFI is a key engineering parameter used in environmental flow calculations, which are required to protect the ecological health of a river. Currently, there are multiple dams proposed in the Basin, as outlined in the National Irrigation Plan. Proposed designs appear to have been based on annual baseflows and would benefit from updating their calculations to consider the seasonal differences.

The long-term sustainability of the catchment should be evaluated in areas which have indicated a decrease in groundwater levels. The results should also be of interest to the Malawian energy sector, specifically the hydropower schemes of Kapachira I and II, located in close proximity to gauge 1L12 which showed a decreasing trend in BFI [36]. Finally, these results add to current knowledge and understanding of baseflow and groundwater discharge to rivers in the SRB. This will be particularly relevant to the new National Water Resources Authority and the SRB Management Programme who are both working in support of sustainable management and development of water resources.

\section{Conclusion}

This study characterizes groundwater discharge to rivers in the Shire River Basin, Malawi, and provides the first comprehensive study of baseflow in the Basin.

The results show that baseflow is an important component of river flow in the Basin which varies both spatially and temporally. For example, average annual BFI ranged from 0.19 (Rivirivi) to 0.97 (Shire), average wet season BFI ranged from 0.23 (Chisombezi) to 0.95 (Shire), and average 
dry season ranged from 0.49 (Ruo) to 0.98 (Shire). Baseflow in especially important to river flow in the dry season, as evidenced by dry season BFI found to be $>0.75$ for most gauges, indicating $75 \%$ of the total river flow is being derived from baseflow from groundwater. This highlights the importance of groundwater in sustaining dry season river flows, which are critical for water supply when rainfall and surface runoff are reduced to a minimum during these months. Several gauges, however, did not see an increase in dry season BFI when compared to the annual and wet season BFI. For example, the dry season BFI found for 14C2 (0.53) only showed a slight increase from the wet season BFI (0.37), and similarly for $14 \mathrm{C} 8$, the dry season BFI (0.49) was only slightly higher than the wet season BFI (0.47). The similarity here between the wet season and the dry season BFI, and the lower dry season BFI when compared to the other gauges, emphasizes the dynamic behavior of baseflow under the influence of natural and anthropogenic factors which vary from in time and space. Long term behavioral changes in the baseflow were evident across the annual, wet and dry season periods. Such changes in baseflow indicate changes to the water cycle and the decreasing trends found here (1L12, $14 \mathrm{~A} 3,14 \mathrm{~B}$ and $1 \mathrm{M}$ ) may be considered a proxy indicator of decreasing groundwater levels in the area. This will be of interest to the Government of Malawi, specifically the National Water Resources Authority who is responsible for sustainable catchment management of both surface water and groundwater resources in the Basin.

\section{Acknowledgements}

The authors would like to acknowledge financial support by the Scottish Government through the Climate Justice Fund: Water Futures Programme (research grant HN-CJF-03) and by the University of Strathclyde. They would also like to acknowledge our partners the Government of Malawi, specifically the Surface Water Division and the Groundwater Division for providing data for this study.

\section{References}

[1] Bierkens, M. F.; Wada, Y. Non-renewable groundwater use and groundwater depletion: a review. Environmental Research Letters 2019, 14, 063002.

[2] Gleeson, T.; Richter, B. How much groundwater can we pump and protect environmental flows through time? Presumptive standards for conjunctive management of aquifers and rivers. River research and applications 2018, 34, 83-92.

[3] Kelly, L.; Kalin, R. M.; Bertram, D.; Kanjaye, M.; Nkhata, M.; Sibande, H. Quantification of temporal variations in base flow index using sporadic river data: application to the Bua catchment, Malawi. Water 2019, 11, 901.

[4] Winter, T. C. Ground water and surface water: a single resource; DIANE Publishing Inc., 1998; Vol. 1139.

[5] UNESCO Surface water and groundwater interaction. A contribution to the International Hydrological Programme.
International Commision on Groundwater 1980.

[6] Hendriks, D.; Kuijper, M.; Van Ek, R. Groundwater impact on environmental flow needs of streams in sandy catchments in the Netherlands. Hydrological Sciences Journal 2014, 59, 562-577.

[7] De Graaf, I. E.; Gleeson, T.; van Beek, L. R.; Sutanudjaja, E. H.; Bierkens, M. F. Environmental flow limits to global groundwater pumping. Nature 2019, 574, 90-94.

[8] Mukherjee, A.; Bhanja, S. N.; Wada, Y. Groundwater depletion causing reduction of baseflow triggering Ganges river summer drying. Scientific reports 2018, 8, 12049.

[9] International Hydrological Programme of UNESCO. Groundwater Resources Assessment under the Pressures of Humanity and Climate Changes GRAPHIC. 2006.

[10] Donoso, M.; Di Baldassarre, G.; Boegh, E.; Browning, A.; Oki, T.; Tindimugaya, C.; Vairavamoorthy, K.; Vrba, J.; Zalewski, M.; Zubari, W. International Hydrological Programme (IHP) eighth phase: Water security: responses to local, regional and global challenges. Strategic plan, IHP-VIII (2014-2021). 2012.

[11] Liu, D.; Chang, J.; Tian, F.; Huang, Q.; Meng, X. Analysis of baseflow index based hydrological model in Upper Wei River basin on the Loess Plateau in China. Proceedings of the International Association of Hydrological Sciences 2015, 368, 403-408.

[12] Frohlich, K.; Frohlich, W.; Wittenberg, H. Determination of groundwater recharge by baseflow separation: regional analysis in northeast China. IAHS Publications-Series of Proceedings and Reports-Intern Assoc Hydrological Sciences 1994, 221, 69-76.

[13] Kouanda, B.; Coulibaly, P.; Niang, D.; Fowe, T.; Karambiri, H.; others Analysis of the Performance of Base Flow Separation Methods Using Chemistry and Statistics in Sudano-Sahelian Watershed, Burkina Faso. Hydrol Current Res 2018, 9, 2.

[14] Ngongondo, C. S. An analysis of long-term rainfall variability, trends and groundwater availability in the Mulunguzi river catchment area, Zomba mountain, Southern Malawi. Quaternary International 2006, 148, 45-50.

[15] Hughes, D. A.; Parsons, R.; Conrad, J. E. Quantification of the groundwater contribution to baseflow; Water Research Commission, 2007.

[16] Lee, J.; Kim, J.; Jang, W.; Lim, K.; Engel, B. Assessment of baseflow estimates considering recession characteristics in SWAT. Water 2018, 10, 371.

[17] Zhang, J.; Zhang, Y.; Song, J.; Cheng, L. Evaluating relative merits of four baseflow separation methods in Eastern Australia. Journal of hydrology 2017, 549, 252-263.

[18] Singh, S. K.; Pahlow, M.; Booker, D. J.; Shankar, U.; Chamorro, A. Towards baseflow index characterisation at national scale in New Zealand. Journal of Hydrology 2019, $568,646-657$.

[19] St. Jacques, J.-M.; Sauchyn, D. J. Increasing winter baseflow and mean annual streamflow from possible permafrost thawing in the Northwest Territories, Canada. Geophysical Research Letters 2009, 36.

[20] Bosch, D. D.; Arnold, J. G.; Allen, P. G.; Lim, K.-J.; Park, Y. S. Temporal variations in baseflow for the Little River experimental watershed in South Georgia, USA. Journal of Hydrology: Regional Studies 2017, 10, 110-121. 
[21] Ahiablame, L.; Chaubey, I.; Engel, B.; Cherkauer, K.; Merwade, V. Estimation of annual baseflow at ungauged sites in Indiana USA. Journal of Hydrology 2013, 476, 13-27.

[22] Government of Malawi. National Water Resources Master Plan 2017. Annex 1: Surface Water Resources. 2017.

[23] Gustard, A.; Bullock, A.; Dixon, J. Low flow estimation in the United Kingdom; Institute of Hydrology, 1992.

[24] Esralew, R. A.; Lewis, J. M. Trends in base flow, total flow, and base-flow index of selected streams in and near Oklahoma through 2008, Scientific Investigations Report 2010-5104. U.S Department of the Interior, U.S Geological Survey 2010.

[25] Zuzani, P.; Ngongondo, C.; Mwale, F.; Willems, P. Examining trends of hydro-meteorological extremes in the Shire River Basin in Malawi. Physics and Chemistry of the Earth, Parts A/B/C 2019.

[26] Jury, M. R. Malawi's shire river fluctuations and climate. Journal of Hydrometeorology 2014, 15, 2039-2049.

[27] Government of Malawi. State of the Basin Report for Shire River Basin. Ministry of Argriculture, Irrigation and Water Development 2016.

[28] Pavelic, P.; Giordano, M.; Keraita, B.; Ramesh, V.; Rao, T. Groundwater availability and use in Sub-Saharan Africa: a review of 15 countries; International Water Management Institute (IWMI), 2012.

[29] Government of Malawi. National Water Resources Master Plan 2017. Main Report: Existing Situation. 2017.

[30] Chitete, S. The Nation "Malawi drying up" https://mwnation.com/malawi-drying-up/ (accessed Apr 16, 2019).

[31] Kumambala, P. G. Sustainability of water resources development for Malawi with particular emphasis on North and Central Malawi (unpublished PhD thesis), 2010.

[32] Chimtengo, M.; Ngongondo, C.; Tumbare, M.; Monjerezi, M. Analysing changes in water availability to assess environmental water requirements in the Rivirivi River basin, Southern Malawi. Physics and Chemistry of the Earth, Parts A/B/C 2014, 67, 202-213.

[33] Government of Malawi. Water Resources Investment Strategy. Component 1 - Water Resources Assessment. Annex I (ii) WRAs 11-17 2011

[34] Government of Malawi. Water Resources Investment Strategy. Component 1 - Water Resources Assessment. Annex II Surface Water 2011.

[35] Government of Malawi. Malawi Hydrogeological and Water Quality Atlas 2018. Ministry of Agriculture, Irrigation and Water Development 2018.

[36] Government of Malawi. Shire River Basin Atlas. Ministry of Agriculture, Irrigation and Water Development 2016.

[37] Government of Malawi. The Shire River Basin Planning Portal. http://shirebasinplanning.wris.info/ 2017.

[38] Fraser, C. M.; Kalin, R. M.; Rivett, M. O.; Nkhata, M.; Kanjaye, M. A national approach to systematic transboundary aquifer assessment and conceptualisation at relevant scales: A Malawi case study. Journal of Hydrology: Regional Studies 2018.

[39] Government of Malawi. Water Resources Investment Strategy.
Component 1 - Water Resources Assessment. Annex I(ii) WRAs 1-4 2011

[40] Miller, A.; Nhlema, M.; Kumwenda, S.; Mbalame, E.; Uka, Z.; Feighery, J.; Kalin, R. M. Evolving water point mapping to strategic decision making in rural Malawi. 2018.

[41] Truslove, J. P.; VM Miller, A.; Mannix, N.; Nhlema, M.; Rivett, M. O.; Coulson, A. B.; Mleta, P.; Kalin, R. M. Understanding the functionality and burden on decentralised rural water supply: Influence of Millennium Development Goal 7c coverage targets. Water 2019, 11, 494.

[42] Kalin, R. M.; Mwanamveka, J.; Coulson, A. B.; Robertson, D. J.; Clark, H.; Rathjen, J.; Rivett, M. O. Stranded assets as a key concept to guide investment strategies for sustainable development goal 6. Water 2019, 11, 702.

[43] Rivett, M. O.; Miller, A. V.; MacAllister, D. J.; Fallas, A.; Wanangwa, G. J.; Mleta, P.; Phiri, P.; Mannix, N.; Monjerezi, M.; Kalin, R. M. A conceptual modelbased framework for pragmatic groundwater-quality monitoring network design in the developing world: Application to the Chikwawa District, Malawi. Groundwater for Sustainable Development 2018, 6, 213-226.

[44] Government of Malawi. Final Report for consultancy services related to detailed design of the upgraded Kamuzu Barrage. Extracts from Main Report Chapters 4 - 11 related to Hydrology - Hydraulics - Water Demand. Ministry of Water Development and Irrigation 2013.

[45] UNESCO Southern Africa FRIEND Phase II 2000-2003; 2004.

[46] Institute of Hydrology. Low Flow Studies Report No 3; Institute of Hydrology, Wallingford, UK, 1980.

[47] Mann, H. B. Nonparametric tests against trend. Econometrica: Journal of the Econometric Society 1945, 245-259.

[48] Kendall, M. G. Rank correlation methods; 4th ed.; Griffin, London, 1975.

[49] Shu, Y.; Villholth, K. G. Analysis of flow and baseflow trends in the Usangu Catchment, Tanzania. 2012.

[50] Zhang, X. S.; Amirthanathan, G. E.; Bari, M. A.; Laugesen, R. M.; Shin, D.; Kent, D. M.; MacDonald, A. M.; Turner, M. E.; Tuteja, N. K. How streamflow has changed across Australia since the 1950s: evidence from the network of hydrologic reference stations. Hydrology and Earth System Sciences 2016, 20, 3947.

[51] Techamahasaranont, J.; Shrestha, S.; Babel, M. S.; Shrestha, R. P.; Jourdain, D. Spatial and temporal variation in the trends of hydrological response of forested watersheds in Thailand. Environmental Earth Sciences 2017, 76, 430.

[52] Addinsoft XLSTAT statistical and data analysis solution. Long Island, New York, USA 2019.

[53] Beck, H. E.; van Dijk, A. I. J. M.; Miralles, D. G.; de Jeu, R. A.; Bruijnzeel, L. A. (Sampurno); McVicar, T. R.; Schellekens, J. Global patterns in base flow index and recession based on streamflow observations from 3394 catchments. Water Resources Research 2013, 49, 7843-7863.

[54] Ahiablame, L.; Sheshukov, A. Y.; Rahmani, V.; Moriasi, D. Annual baseflow variations as influenced by climate variability and agricultural land use change in the Missouri River Basin. Journal of hydrology 2017, 551, 188-202. 
[55] Ngongondo, C. S.; Xu, C.-Y.; Tallaksen, L. M.; Alemaw, B.; Chirwa, T. Regional frequency analysis of rainfall extremes in Southern Malawi using the index rainfall and L-moments approaches. Stochastic Environmental Research and Risk Assessment 2011, 25, 939-955.

[56] Palamuleni, L. G. C. Land cover change and hydrological regimes in the Shire river catchment, Malawi, 2009.

[57] Killian, C. D.; Asquith, W. H.; Barlow, J. R.; Bent, G. C.; Kress, W.
H.; Barlow, P. M.; Schmitz, D. W. Characterizing groundwater and surface-water interaction using hydrograph-separation techniques and groundwater-level data throughout the Mississippi Delta, USA. Hydrogeology Journal 2019, 1-13.

[58] Palamuleni, L. G.; Ndomba, P. M.; Annegarn, H. J. Evaluating land cover change and its impact on hydrological regime in Upper Shire river catchment, Malawi. Regional Environmental Change 2011, 11, 845-855. 